\title{
INCREASING INTEREST OF STUDENTS IN CHEMISTRY TROUGH SELF-DEPENDENT STUDIES BY USING MODERN INFORMATION TECHNOLOGIES
}

\section{Daina Možeika, Dagnija Cēdere}

Faculty of Chemistry, University of Latvia, Latvia

\begin{abstract}
It can be observed that student's interest in chemistry has a tendency to decrease in the schools of Latvia. As information technologies in the world develop possibilities to use computer and Internet in everyday life are increasing. Internet is becoming an integral part of daily life not only for adults but also for school children.

It should be mentioned, that appropriate information technology equipment is lacking in many natural sciences classrooms of schools in Latvia. Schools are trying to solve these situations by equipping chemistry classrooms with at least one computer and projector. Therefore teachers have a chance to obtain skills for working with IT.

The use of Internet and IT is stimulating factor to raise students' interest in chemistry, therefore a method was developed which is based on enhancing students' interest in chemistry by using Internet and IT at home. Under students' extracurricular activities students search for information about a chemistry topic in Internet and prepare a presentation on it. Student's attention and thoughts are concentrated on chemistry at full scale. The obtained information, impressions and memories are long term and enable to maintain interest in students.

The students' finished work is evoking interest in chemistry and a motivated attitude is formed against the subject, accomplished work and mainly against oneself. The method takes into consideration individual personal traits and expressions of students.

Since the self-dependant work of students is fulfilling educational and developmental function it is also recommended to be used for teaching other school subjects.
\end{abstract}

Key words: attitude, chemistry, interest, information technologies, studying process.

\section{Introduction}

It can be observed that students interest in chemistry has a tendency to decrease in the schools of Latvia. This is also supported by international studies ROSE and TIMSS. (Mozeika, Cedere, Gedrovics, 2007). As information technologies (IT) in the world develop possibilities to use computer and Internet in everyday life are increasing. Internet is becoming an integral part of daily life not only for adults but also for school children. Students are spending most of their time at the computer not only when preparing a paper in certain subjects (Porozovs, Praulite, Gedrovics, 2006). Most often students use Internet to contact their friends or classmates. Integral advantage of Internet is the time saved and the speed of finding information, although often the time spent for information search increases because at the same time student is able to obtain information which is not necessary but seems more interesting and exciting. It can be recommended to use the broad possibilities of Internet for enhancing students interest in expanding their views and to form the understanding that Internet is not ending at correspondence with friends or playing computer games, but that Internet can also be used in a more useful way - for obtaining new information that could help in better understanding of certain subjects at school.

It should be mentioned, that appropriate information technology equipment is lacking in many natural sciences classrooms of schools in Latvia. Most often the lessons where it is supposed to use Internet are planned to be placed in computer classrooms and this is giving difficulties for the organizational system of school. Frequent change of classrooms is not easy for students either and taking into account the busy rhythm of school, sometimes it is even 
impossible. That unfortunately is the reason why IT in chemistry lessons is seldom used. Students' computer skills are usually good. Often they have better knowledge in IT than teachers do, because they use computers more often in their daily life.

Schools are trying to solve these situations by equipping chemistry classrooms with at least one computer and projector. Therefore teachers have a chance to obtain skills for working with IT. This is also a great possibility to show the interdisciplinary bond of school subjects working in practice, what otherwise is denied and thought of as unlikely by students.

More often teachers choose to conduct classical chemistry lessons on the grounds that students get enough virtual experience in informatics lessons and elsewhere. Therefore more importance is still turned to the content of studies but not to make students' learning and perception easier. Of course it takes more time from the teacher to prepare a lesson where it is supposed to use IT. Orientation skills in all the offered Internet information and ability in dealing with technologies are necessary.

It is proven that IT use at home is an enhancing factor to stimulate students' interest in science education (Lamanauskas, Vilkonis, Klangauskas, 2006), and classmates should also be informed about the obtained information (Moine, 2007). This approach is seldom used in teaching chemistry in Latvia.

The method is tended to enhance interest of students in chemistry, it can be recommended to students to use extracurricular activities under which students could search for information in Internet about a topic which they are interested in and prepare a presentation on it. It would allow elevate interest of students in chemistry, to form motivated attitude to different events in the world.

\section{Method}

The essence of method is based on enhancing students' interest by using IT and Internet at home which would be enhancing factor in raising students' interest in chemistry and worldwide important chemical processes in nature. Knowledge obtained by students from going into detail of some chemistry topic would raise interest to in depth studies of processes in nature and follow their changes.

The methodological approach can be abstracted and generalized with scheme which is based on interconnection of interest- knowledge - attitude (Figure 1)
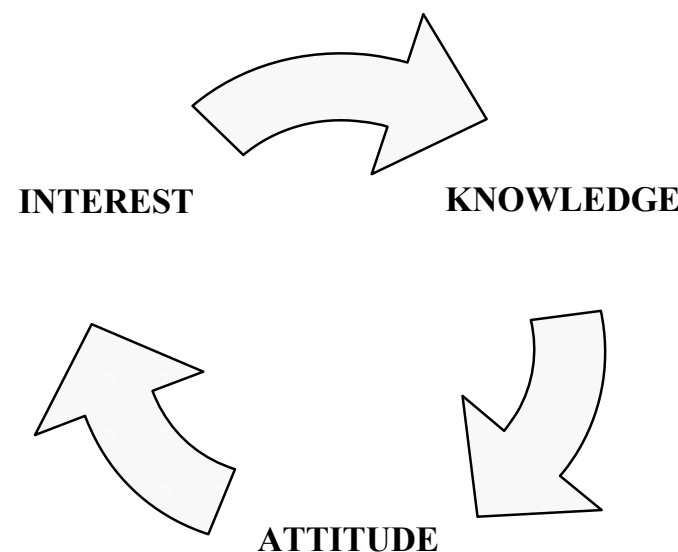

ATTITUDE

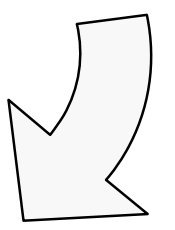

ATTITUDE

Figure 1. Method for enhancing interest put in the scheme. 
Students' self-dependent work in chemistry when using IT can be implemented in three stages (Figure 2).

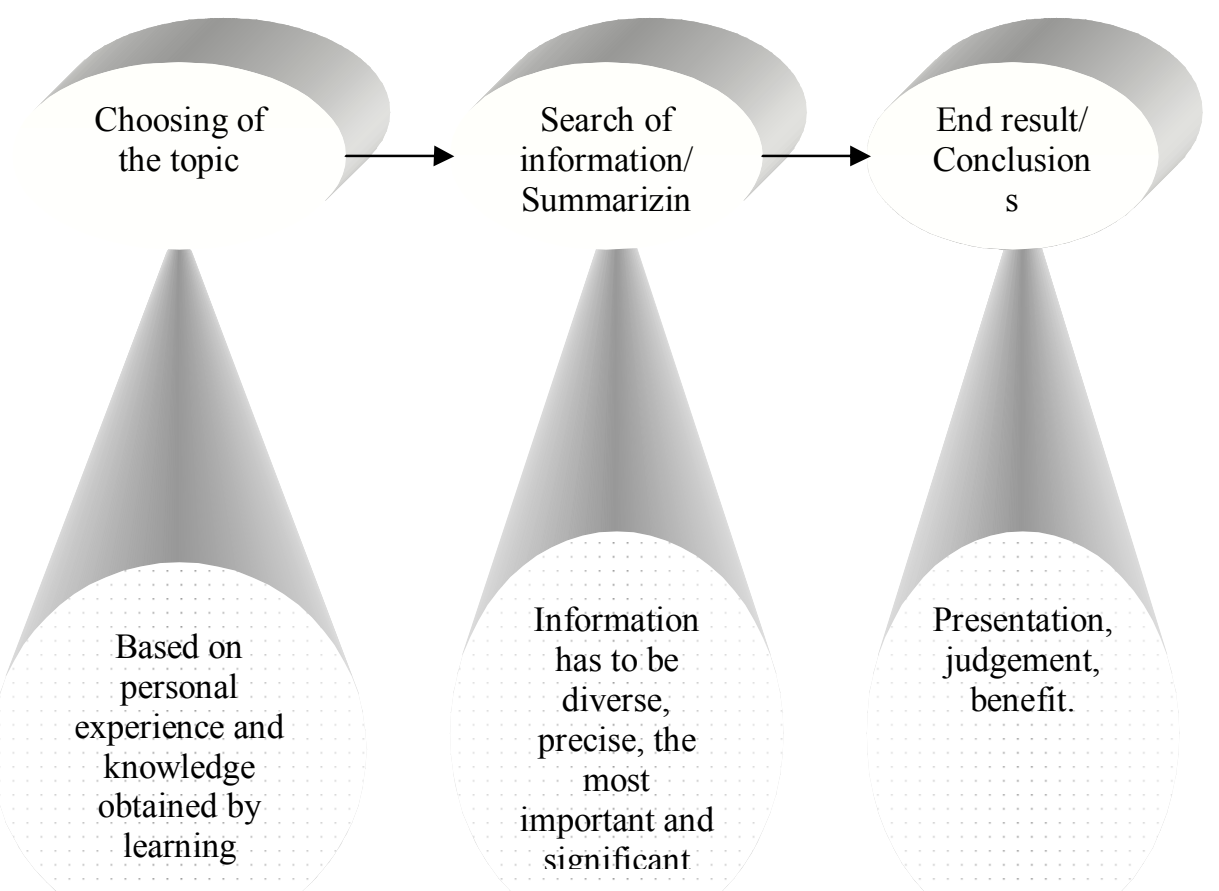

Figure 2. Stages of students self-dependent work.

Students have an opportunity to choose topic themselves. Topic can be a global problem, domestic scale issue or topic on natural sciences. In case students can not pick their topic, several themes can be offered, for example, glacier melting, drinking water in Latvia and in the world, chemical pollution, health and chemistry, fragrance chemistry, agricultural chemistry a.o.

For the implementation of the method students of 8th-12th grade were adjusted. Students' self-dependent work can be carried out individually or in groups of 2-3, depending on the topic or personal traits of student's character. dependent work.

In the beginning students are introduced with a plan and valuation criteria of the self-

Procedure of the self-dependent work:

1. Selection of the topic

2. Search for information/aggregation of information

3. Presentation of the studies

4. Answers to questions

5. Analysis and valuation 


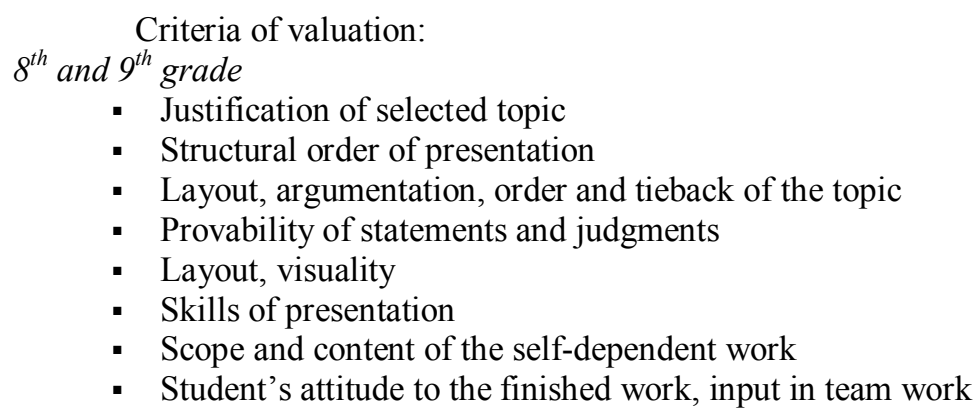

$10^{\text {th }}-12^{\text {th }}$ grade

- Justification of selected topic, its urgency

- Defined aims and tasks

- Structural order of presentation

- Versatility of subject layout

- Layout, visuality

- Analysis of information, conclusions

- Argumentation, individual opinion

- Scope and content of the self-dependent work

- Scope and depth of knowledge

- Answers to questions

- Student's attitude to the finished work, input in team work

In valuation students attitude has to be especially taken into account. During the presentation a special student's card has to be completed. It is done by teacher, classmates and at the end by the student itself. Valuation can be done according to point system (at teacher's choice) in compliance with previously proposed criteria. The endvalue of student's selfdependent work is mean value formed from teacher's valuation, self-valuation and classmates' valuation.

The essence of this teaching method is based on enhancing interest of students in chemistry by use IT. Based on the fact that nowadays students have great interest in IT, it is possible to use it in chemistry teaching to achieve raise of students' interest. At the stage of information search new knowledge is obtained, but the whole process in its turn forms a positive attitude in student for IT use in learning chemistry. For many students information on urgent and global events based on chemical processes from Internet enhances motivated attitude to chemistry in general.

Students' self-dependency and teacher's trust in them facilitate mutual cooperation and understanding during the teaching process. Thus teacher has an opportunity to make students think broader about the general meaning of chemistry not only in chemistry lessons but also in daily life.

Taking part in this self-dependent work is not obligatory for a student, but it is recommended. Students can carry out this work during the whole study year, however coordinating the presentation time with the teacher.

The same as in Estonia (Жикина, Портянская, 2007) students of Latvia are advised to use the following search programms and home pages into searching for Internet resources:

- $\quad$ http://www.chemistry.ssu.samara.ru/

- $\quad$ http://www.informika.ru/text/database/chemy/Rus/chemy.html

- $\quad$ http://www.chemsoc.org/timeline/index.html

- $\quad$ http://www.chem.ox.ac.uk/vrchemistry/foundation.html 
- http://www.colby.edu/chemistry/OChem/demoindex.html

- http://ull.chemistry.uakron.edu/genobc/

- http://www.chemistry.hut.ru/

- http://orgchem.city.tomsk.net/

- http://www.chem.msu.su/rus/library/welcome.htm\#teaching

- $\quad$ http://www.pmedia.ru

In Latvia students are tended to use these addresses more frequently than abovementioned:

- http://youtube.com/

- http://www.kakao.lv/

- $\quad$ http://lv.wikipedia.org

- $\quad$ http://en.wikipedia.org

- $\quad$ http://webct.lanet.lv/webct/public/home.pl

- http://www.dansdata.com/magnets.htm

- http://ipul.lv/new/

- http://www.liis.lv/vi/vigpies.htm

- http://www.liis.lv/vi/viudpies.htm

- http://www.bef.lv/?s=177

- http://www.lva.gov.lv/zinojumi/wfd2005_lv/Pielikums_3_1_2_3.pdf

- $\quad$ http://www.blogs.lv/raksti/

The method is approbated in all grade groups. The initial scepsis and negative attitude of students start to change and interest to get to know more is appearing. Fragments of video materials are also used in preparing presentations. There was a creative atmosphere in the classroom at the time of students' self-dependent work and students' attention was maximally concentrated and tagged to chemistry topics. In addition, after the lesson students often wanted to know which Internet address was used for the particular information. In this way students exchanged information which could be useful.

Students are trying to prepare the papers on their chosen topic accurately because valuation of the finished work is by great extent judged after student's attitude and to lesser extent after obtained formal knowledge and compliance to other criteria of valuation. Positive tendencies are observed in changes of individual experience and attitude, when student had been going into details of some chemistry topic. It should be mentioned that more accurate and active involvement in self-dependent work was done by students with comparatively low achievements in studies in general. Students see a perspective to get comparatively high valuation, which will be taken into account when assessing the final valuation of the school year.

\section{Discussion}

A method is developed which is based on enhancing students' interest by using IT and Internet at home, which is stimulating factor to raise students' interest in chemistry, by being able to go into details of some chemistry topic. Under students' extracurricular activities they search for information about a chemistry topic in Internet and prepare a presentation on it. Student's attention and thoughts are concentrated on chemistry at full scale. The obtained information, impressions and memories are long term and enable to maintain interest in students.

The students' finished work is evoking interest in chemistry and a motivated attitude is formed against the subject, accomplished work and mainly against oneself. The individual 
experience and attitude of students is changing in a positive way. The method takes into consideration individual personal traits and expressions of students. Students obtain broader view that learning process in chemistry does not only end at teacher's narration and laboratory lessons, but that with the use of IT is possible to obtain more diverse information and view on chemistry and chemical processes in the nature.

Students with comparatively low achievements in studies involve in the offered selfdependant work. Since the self-dependant work of students is fulfilling educational and developmental function it is also recommended to use it for other school subjects.

\title{
References
}

Lamanauskas, V., \& Vilkonis, R., Klangauskas A. (2006). Using Information and Communication Technology for Learning Purposes: Students' Position on the Issue. $5^{\text {th }}$ IOSTE and Central European Symposium-Europe needs more Scientists, Tartu, Estonia, 151-165.

Moine, C. (2007). Explor@mobile: using new technologies to teach science to teenagers. SCIENCE in School, 4, 35-37.

Možeika, D., \& Cēdere, D., Gedrovics, J. (2007). Skolēnu interese apgūt ķīmijas jautājumus: tendences 2003-2007. Konferences "Ķīmijas izglìtība skolā 2007” rakstu krājums, 64-73.

Porozovs, J., \& Praulite, G., Gedrovics, J. (2006). Students` Interest and Practical Experience in Natural Science in Latvia at the Primary and Middle School Levels. $5^{\text {th }}$ IOSTE and Central European Symposium-Europe needs more Scientists, Tartu, Estonia, 34-45.

Жикина, И., \& Портянская, И. (2007). Использование возможностей ИКТ в методике преподавания химии. Science Education in a Changing Society, 1, 120-125.

Received 24 September 2007; accepted 05 October 2007

\section{Daina Možeika}

Centre of Chemistry Didactics,

Faculty of Chemistry, University of Latvia

Kr. Valdemāra iela 48, LV-1013 Rīga, Latvia

E-mail: tuttii@inbox.lv

\author{
Dagnija Cēdere \\ Centre of Chemistry Didactics, \\ Faculty of Chemistry, University of Latvia \\ Kr. Valdemāra iela 48, LV-1013 Rīga, Latvia \\ E-mail: dagnija.cedere@lu.lv
}

